\title{
Mathematical Modelling: A Comparatively Mathematical Study Model Base between Corruption and Development
}

\author{
Sayaji Rastum Waykar \\ (Research Scholar, JJT, University, Rajasthan) \\ Assistant Professor, Department of Mathematics \\ Yashwantrao Chavan Mahavidyalaya, Halkarni \\ Tal: Chandgad, Dist: Kolhapur, Maharashtra (India).
}

\begin{abstract}
In this paper, we have studied on the topic of 'Corruption'. Also, I will try to find or study the effect of corruption on the Development of the country or any country of the world. Therefore, how find the solution of the problem of corruption will be destroyed completely from the society. We have observed that the Development of the country depends upon Corruption. That is, when the Corruption increases, Development decreases automatically of any country of the world. Therefore, I will try to find the formula on the problem of 'Relation between the Corruption and Development of any field or any country of the world'.

Also, I have to highlight the concept of 'Application of Mathematical modeling in the interesting problem "corruption" in every field of our country or world. Also, Applied Mathematics focuses on the formulation and study of Mathematical Models.Thus the activity of Applied Mathematics is vitally connected with Research in Pure Mathematics. So I will try to study on it and find, what is corruption and quantity of corruption and also find the growth of corruption and how it will decay?

Now we convert this areal world problem to mathematics problem and find some formulae on it such as Mathematical Corruption Growth formula, Mathematical Constant corruption level formula and Mathematical decay of corruption formula.
\end{abstract}

Keyword: applied, modelling, fuzy, mathematical thinking, corruption mentality.

\section{Introduction:}

Mathematics is the most important subject as compared to the other because it has a lot of branches and techniques for finding the formulae on the problem of various fields in the world. It is applied techniques like 'Advances in computational Mathematics', In this branch Mathematical framework is used for solving various problems of science and Technology and Application of differential equation is a truism that nothing is permanent except change and the primary purpose of differential equations is to serve as a tool for the study of change in the physical world and also. So we have to use the mathematical framework and applied technique for studying the relation between Corruption and Development in each and every field of the country India or world.

Also, I have to highlight the problem of 'corruption' in front of our country or the world. Because, present days, every person in society is suffering from corruption in every field such as Government offices, Educational offices, politicians and Judiciary and its related officers of various courts of our country and others etc. So that corruptions have removed completely from the society. Therefore, I will try to find the quantity of corruption in our country at any time. Also I will try to find the solution for reducing the growth of corruption from the society as well as in all other field of our country.

\section{Methodology:}

We have to use the seven steps of mathematical modelling cycle for solving the problem of corruption in the society of any country of the world. Mathematical modelling means, a translation from rest of world to mathematics world. Also, Mathematical model building involves imagination and skills. We can solve any problem of rest of world by using mathematical modelling.

The mathematical modelling process is as follows: 


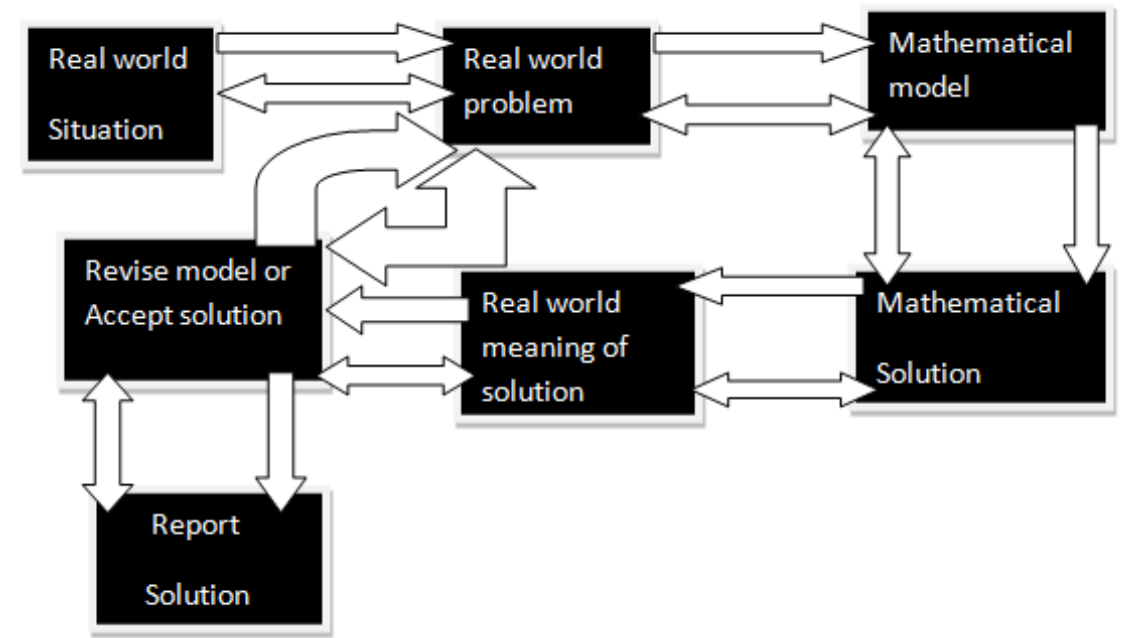

"Mathematical Modelling Process"

This is known as seven stage of mathematical modelling process.

\section{1: What is Corruption or MC-Model?}

III. Mathematical Corruption Model:

Mathematical Corruption or MC-Model is defined as it is a psychological diseases such that

* Primary stage: Do the work but get benefit or more,

* Medium stage: Not do the work without benefit,

* Last stage: Without work but get benefit or more.

Note that benefit belongs to money or gift or other facility.

3.2: What is K or Mathematical E-virus constant? :

The Mathematical E-virus constant $\mathbf{K}$ is defined as sum of the negative characters of person lead to increase the corruption or MC-Model. It is,

$$
\therefore \mathrm{K}=\sum_{i=1}^{i=8} C_{i}, \quad-1<\mathrm{K}<1 \text {. }
$$

Where,

$\boldsymbol{C}_{1}=$ Not sincere,

$C_{2}=$ Principle less,

$C_{3}=$ Unfaithful,

$\boldsymbol{C}_{4}=$ Not devotion to work or duty,

$C_{5}=$ Not punctuality,

$C_{6}=$ Misbehaviors,

$\boldsymbol{C}_{7}=$ Irregular to duty or work,

$C_{8}=$ Not attachment to work or duty.

The constant $\mathbf{K}$ belongs to all the above characters are known as constant of proportionality.

It is also known as 'Mathematical Effected Virus constant' or Mathematical E-virus constant.

Note that the E-virus constant $\mathbf{K}$ has main role for strongly increasing the corruption or $\mathbf{C}$-disease. Mathematical E-virus constant is very effective because when it reacts the persons then its poison increases slowly and slowly up to the ten years after that the person will become completely C-disease or Corruption disease.

\section{Types of Corruptions:}

There are three types of Corruptions such as

I) Negative Corruption:

It is the quantity in which the Mathematical E-virus constant $K$ is less than zero. It has done in particular situations of a person. It is very useful for the health of the society.

\section{II) Constant Corruption:}

It is the quantity in which Mathematical E-virus constant $\mathrm{K}$ is equal to zero. If it has done always when Mathematical E-virus constant $\mathrm{K}$ is equal to zero then the health of the society in the country or world will become strong. 


\section{III) Positive Corruption:}

It is the quantity in which Mathematical E-virus constant $K$ is greater than zero. If it has done then the health of the society in the country or world will become very weak or sick.

\section{Mathematical Constant corruption level :}

It is defined as, 'When $K=0$, that is , 'The Authority or chairperson or person had helped in humanity to the some people in their particular circumstances or situations without follows the rules and regulations of that Institutions or state or country.' It is known as Mathematical Constant Corruption level. It is always in every country in every year. Therefore, the quantity is

$$
\mathrm{C}=C_{0} \text {, when } \mathrm{K}=\mathbf{0} \text {. }
$$

It is also known as 'Initial Corruption level.' It is the quantity that is, the negative corruption increases up to the Constant corruption when $\mathbf{K} \leq \mathbf{0}$. Further the quantity $\mathbf{C}=\boldsymbol{C}_{0}$ will not change when the Mathematical E-virus Constant is equal to zero that is $\mathbf{K}=\mathbf{0}$ and it is used for the development of the peoples who are living in the society. So we say the negative corruption is very useful or very good for the health of the society in the country or world. But if Mathematical E-virus Constant is greater than zero then the positive corruption increases. This is very dangerous for the health of the society in the country or world and the development of the society decreases. The graph of Mathematical Constant Corruption level is as follows:

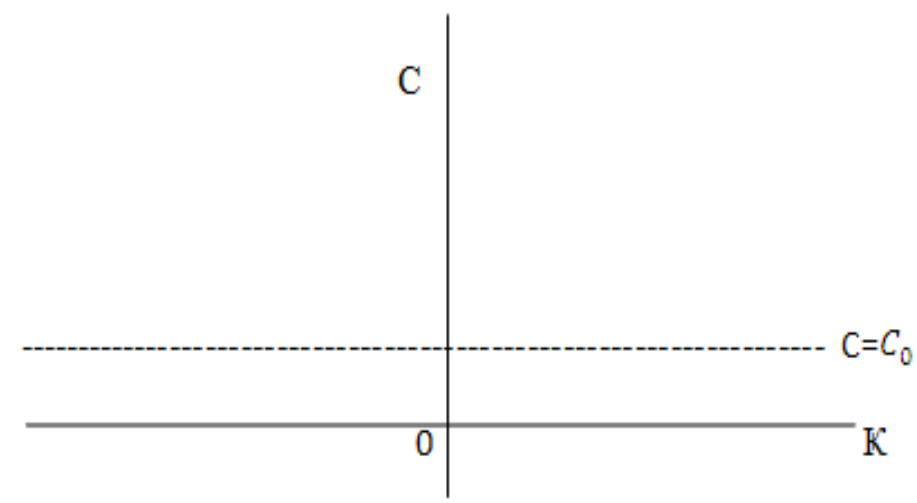

Fig1: Graph of 'Mathematical Constant Corruption level'.

\section{Mathematical Corruption Model or Mathematical Corruption growth formula:}

Suppose the rate of growth of corruption at any time $\mathrm{t}$ is proportional to the number $\mathrm{C}$ present at that time.

If $\mathrm{C}$ is number of corruption at time $\mathrm{t}, \frac{d C}{d t}$ is rate of growth of the corruption.

Then growth law, in short is $\frac{d C}{d t} \propto_{\mathrm{C}}$

$\therefore \frac{d c}{d t}=\mathbf{K} \mathbf{C}$, where $\mathbf{K}$ is constant of proportionality and it denotes the characters of person which leads to increase the corruption.

$$
\therefore \quad \frac{d C}{C}=\mathbf{K} \mathrm{dt}
$$

Therefore variables are separable, then integrating to the both side, we get

$$
\begin{aligned}
& \therefore \log _{e} \mathrm{C}=\mathbf{K t}+\mathbf{c} \\
& \therefore \quad \mathrm{C}=e^{\mathrm{Kt}+\mathbf{c}} \\
& \therefore \quad \mathrm{C}=e^{\mathrm{Kt}} e^{\mathrm{c}} \\
& \therefore \quad \mathrm{C}=c_{1} e^{\mathrm{Kt}}, \text { where } e^{c}=c_{1}
\end{aligned}
$$

Initially, when $\mathrm{t}=0, \mathrm{C}=C_{0}$

$$
\therefore \text { From (ii), } C_{0}=c_{1} e^{0} \quad \therefore C_{0}=c_{1}
$$

Putting in (i), we have

$$
\therefore \quad \mathbf{C}=\boldsymbol{C}_{\mathbf{0}} e^{\mathrm{Kt}} \text {, when } \mathrm{K}>\mathbf{0}
$$


This is known as Mathematical Corruption growth formula or MC-Model.

\section{Mathematical Decay law of Corruption formula:}

When $K>0$, the Corruption will increase and increase to the maximum level.

At this level we say, it is very high quantity of Corruption to each and every field in our country or world. That is, every person in society is suffering from Corruption in every field such as Government offices, Educational offices, politicians and Judiciary of our country and others etc. which leads to all over development decreases, so that corruptions have removed completely from society, then the country will be developed in each field.

So, if we will try to control to grow of Corruption by reducing the value of E-virus $K$. If E-virus constant $K$ reduces to zero $(0)$, that is removing all the (-ve) characters of persons belonging in $K$ then the Corruption $(\mathrm{C})$ will reach to Mathematical Constant corruption level $\left(C_{0}\right)$. So we find formula,

$$
\therefore \quad \mathbf{C}=\boldsymbol{C}_{0} e^{-\mathrm{Kt}} \text {, when } \mathbf{K} \leq \mathbf{0} \text {---------- (iv) }
$$

It is known as Mathematical Decay law of Corruption formula and the graph of these laws is as follows:

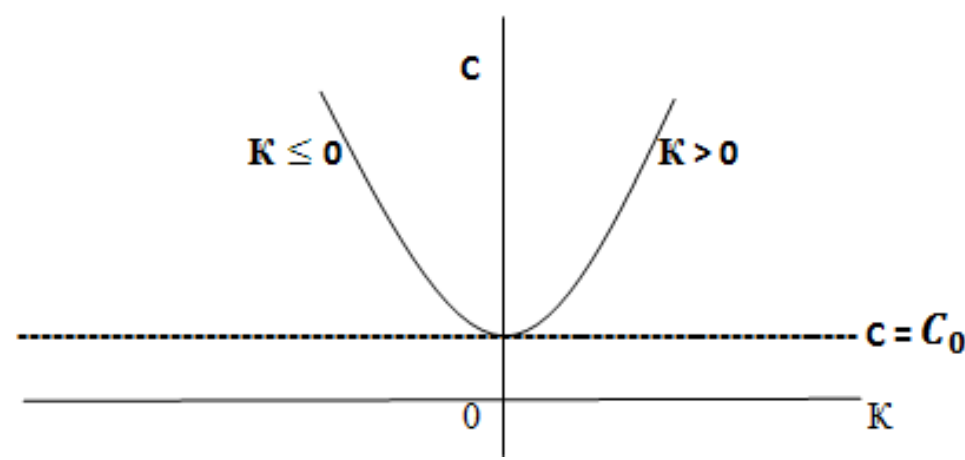

Fig-2: Graph of 'Decay and Growth laws of Corruption'.

\section{The study of Mathematical Model base on the Corruption and Development:}

The rate of change of Development per unit (-ve) Corruption is directly proportional to the Development. If $\mathrm{D}$ is the number of development per unit corruption $\mathrm{C}, \frac{d D}{d C}$ is the rate of growth of development then

$$
\therefore \quad \frac{d D}{d C} \alpha D
$$

Therefore, the present problem is governed by the differential equation

We have,

$$
\therefore \frac{d D}{d C}=K D
$$

Subject to the condition, $\mathrm{D}(0)=D_{0}$

Separating the variables in equation (i) and integrating to the both side, we have

$\therefore \quad \int \frac{d D}{D}=\int K d c+\alpha$ where $\alpha_{i}$ constant of integration.

$$
\begin{aligned}
& \therefore \log D=\mathrm{KC}+\alpha \\
& \therefore \mathrm{D}=e^{\mathrm{KC}+\alpha} \\
& \therefore \mathrm{D}(\mathrm{C})=c e^{\mathrm{KC}}, \text { where } e^{\alpha}=\mathrm{c}
\end{aligned}
$$

Initially, corruption $\mathrm{C}=0, \mathrm{D}=\mathrm{D}(0)=D_{0}$

$$
\begin{aligned}
& \therefore \text { From (ii), } D_{0}=\mathrm{c} \text { putting in (ii), we have } \\
& \therefore \text { From (ii), } \\
& \therefore \quad \mathbf{D}(\mathbf{C})=\mathbf{D}(\mathbf{0}) e^{\mathrm{KC}}
\end{aligned}
$$

This is the formula of 'Relation between Corruption and Development.'

Also, from equation (iii),

$$
\begin{array}{ll}
\therefore \quad & e^{\mathrm{KC}}=\frac{D(C)}{D(0)} \\
\therefore & e^{\mathrm{K}}=\left[\frac{D(C)}{D(0)}\right]^{\frac{1}{C}}
\end{array}
$$


By taking logarithm on both sides,

We have,

$$
\therefore \mathrm{K}=\frac{1}{C} \log \frac{D(C)}{D(0)}
$$

Where $K$ denotes the Mathematical E-virus constant that is (-ve) characters of person which leads to increase the Corruption.

\section{Illustrations:}

\subsection{Mathematical Corruption Growth in the Country (general) India:}

Suppose, we assume that there was no corruption in the country, India at 15 August, 1947 (That was time our nation India became freedom from British) and our nation population was 35 crore at that time. Therefore, corruption $\mathrm{C}=0$, when $\mathrm{t}=0$.

After 10 years, 15 August, 1957, corruption was one percentage of old population, that is $\mathrm{C}=0.35$ crore.

$$
\text { We know that, }
$$

$$
\begin{array}{cr}
\therefore \quad & \mathbf{C}=\boldsymbol{C}_{\mathbf{0}} e^{\mathrm{Kt}}, \mathbf{K}>\mathbf{0} . \\
\therefore & 0.35=C_{0} e^{10 \mathrm{~K}}
\end{array}
$$

But we take $\mathrm{K}=0$, we have

$$
\begin{array}{ll}
\therefore & 0.35=C_{0} e^{0} \\
\therefore & 0.35=C_{0}, \text { where } e^{0}=1 . \\
\therefore & C_{0}=0.35 \text { crore }
\end{array}
$$

Putting in (vi), we get

$$
\therefore \quad \mathrm{C}=0.35 e^{\mathrm{R} t}
$$

Then at 15 August, 1967, the corruption would be double of old.

That is $\mathrm{C}=0.70$ crore in time $\mathrm{t}=10$ years.

$$
\begin{array}{cc}
\therefore \text { From (i), } & 0.70=0.35 e^{10 K} \\
\therefore & e^{10 K}=\frac{0.70}{0.35} \\
\therefore & \left(e^{K}\right)^{10}=2 \\
\therefore & e^{K}=(2)^{\frac{1}{10}}
\end{array}
$$

Putting in (i), we have

$$
\therefore \quad \mathrm{C}=0.35 \times(2)^{\frac{t}{10}}
$$

This is known as Mathematical Model Base Corruption with related time formula.

When $\mathrm{t}=30$ years, what is $\mathrm{C}=$ ?, at 15 August, 1977 .

$$
\begin{gathered}
\therefore \text { From (iii), } C=0.35 \times(2)^{\frac{30}{10}} \\
\therefore \quad C=0.35 \times 8 \\
\therefore \quad C=\mathbf{2 . 8 0} \text { crore. }
\end{gathered}
$$

When $\mathrm{t}=40$ years, $\mathrm{C}=$ ? , at 15 August, 1987.

$$
\begin{array}{ll}
\therefore & \text { From (iii), } \\
\therefore & C=0.35 \times(2)^{\frac{40}{10}} \\
\therefore & C=0.35 \times 16 \\
\therefore & C=\mathbf{5 . 6 0} \text { crore. }
\end{array}
$$

When $\mathrm{t}=50$ years, $\quad \mathrm{C}=$ ? , at 15 August, 1997 .

$$
\begin{array}{ll}
\therefore \text { From (iii), } & C=0.35 \times(2)^{\frac{50}{10}} \\
\therefore & C=0.35 \times 32 \\
\therefore & C=11.20 \text { crore. }
\end{array}
$$


When $\mathrm{t}=60$ years, $\quad \mathrm{C}=$ ? , at 15 August, 2007 .

$$
\begin{array}{ll}
\therefore & \text { From (iii), } \mathrm{C}=0.35 \times(2)^{\frac{60}{10}} \\
\therefore & \mathrm{C}=0.35 \times 64 \\
\therefore & \mathrm{C}=\mathbf{2 2 . 4 0} \text { crore }
\end{array}
$$

Today, when $\mathrm{t}=\mathbf{6 5}$ years, $\quad \mathrm{C}=$ ? , at 15 August, 2012 .

$$
\begin{array}{ccrl}
\therefore & \text { From (iii), } \mathrm{C}=0.35 \times(2)^{\frac{65}{10}} \\
\therefore & & \mathrm{C}=0.35 \times 64 \times 1.414 \\
\therefore & & \mathrm{C}=22.40 \times 1.414 \\
\therefore & & \mathrm{C}=\mathbf{3 1 . 6 7 3 6} \text { crore }
\end{array}
$$

When $\mathrm{t}=70$ years, $\quad \mathrm{C}=$ ?, at 15 August, 2017 .

$$
\begin{array}{ll}
\therefore \text { From (iii), } & \mathrm{C}=0.35 \times(2)^{\frac{70}{10}} \\
\therefore & \mathrm{C}=0.35 \times 128 \\
\therefore & \mathrm{C}=\mathbf{4 4 . 8 0} \text { crore }
\end{array}
$$

When $\mathrm{t}=80$ years, $\quad \mathrm{C}=$ ? , at 15 August, 2027 .

$\therefore$ From (iii), $\mathrm{C}=0.35 \times(2)^{\frac{80}{10}}$

$$
\begin{array}{ll}
\therefore & \mathrm{C}=0.35 \times 2^{8} \\
\therefore & \mathrm{C}=0.35 \times 256 \\
\therefore & \mathrm{C}=\mathbf{8 9 . 6 0} \text { crore }
\end{array}
$$

When $\mathrm{t}=90$ years, $\quad \mathrm{C}=$ ? , at 15 August, 2037.

$$
\begin{array}{ll}
\therefore & \text { From (iii), } \mathrm{C}=0.35 \times(2)^{\frac{90}{10}} \\
\therefore & \mathrm{C}=0.35 \times(2)^{9} \\
\therefore & \mathrm{C}=0.35 \times 512 \\
\therefore & \mathrm{C}=\mathbf{1 7 9 . 2 0} \text { crore }
\end{array}
$$

When $\mathrm{t}=100$ years, $\mathrm{C}=$ ? , at 15 August, 2047 .

$$
\begin{array}{ll}
\therefore \text { From (iii), } \quad C=0.35 \times(2)^{\frac{100}{10}} \\
\therefore \quad C=0.35 \times(2)^{10}=0.35 \times 1024 \\
\therefore \quad C=358.40 \text { crore }
\end{array}
$$

The data of time in years and corruption in crore of country (India) is in tabular form:

\begin{tabular}{|l|l|l|l|l|l|l|l|l|l|}
\hline $\begin{array}{l}\text { Time } \\
\mathbf{t} \text { (years) }\end{array}$ & $0-10$ & $10-20$ & $20-30$ & $30-40$ & $40-50$ & $50-60$ & $60-70$ & $70-80$ & $80-90$ \\
\hline $\begin{array}{l}\text { Corruption } \\
\text { C (crore) }\end{array}$ & 0.35 & 0.70 & 2.80 & 5.60 & 11.20 & 22.40 & 44.80 & 89.60 & 179.20 \\
\hline
\end{tabular}

8.2 Mathematical Growth of Development Model except Corruption:

We assume that there was no corruption on 15 August, 1947 (Freedom date). Therefore $\mathrm{C}=0$ and Development was one percentage of old population.

That is when $\mathrm{C}=0, \mathrm{D}=\mathrm{D}(0)=D_{0}=0.35$ crore

After 10 years from freedom that is 15 August, 1957, $\mathrm{C}=0.35$ crore and

The Development would be double of old that is $\mathrm{D}(\mathrm{c})=0.70$ crore.

Now from (iii), $\mathrm{D}(\mathrm{c})=\mathrm{D}(0) e^{\mathrm{KC}}$

$$
\therefore 0.70=\mathrm{D}(0) e^{0.35 \mathrm{~K}}
$$

But we take $K=0$, where $K$ be the E-virus lead to increase the corruption 


$$
\begin{aligned}
& \therefore \quad 0.70=\mathrm{D}(0) e^{0} \\
& \therefore 0.70=\mathrm{D}(0) \times 1 \\
& \therefore \mathrm{D}(0)=0.70
\end{aligned}
$$

Putting this value in equation (iii), we have

$$
\therefore \mathrm{D}(\mathrm{c})=0.70 \times e^{\mathrm{KC}}
$$

After 20 years from freedom, $\mathrm{C}=0.70$ crore and Development would be double of old that is $\mathrm{D}=1.40$ crore, putting in (ix), we have

$$
\begin{aligned}
& \therefore 1.40=0.70 \times e^{0.70 \mathrm{~K}} \\
& \therefore e^{0.70 \mathrm{~K}}=\frac{1.40}{0.70} \\
& \therefore e^{0.70 \mathrm{~K}}=2 \\
& \therefore e^{\mathrm{K}}=[2]^{\frac{1}{0.70}} \\
& \therefore \mathbf{K}=\frac{1}{0.70} \log 2
\end{aligned}
$$

Putting in (i), we have

$$
\therefore \mathbf{D}(\mathbf{c})=\mathbf{0 . 7 0} \times[2]^{\frac{c}{0.70}}
$$

This is known as Mathematical Model Base Development with related Corruption formula.

After 30 years (15 August 1977) from freedom when corruption $C=2.80$ crore, $D(C)=$ ?

$$
\text { From (ii), } \begin{aligned}
\mathrm{D}(\mathrm{c})= & 0.70 \times[2]^{\frac{2.80}{0.50}} \\
= & 0.70 \times[2]^{\frac{4}{11}} \\
= & 0.70 \times 16 \\
\therefore \mathbf{D}(\mathbf{c}) & =\mathbf{1 1 . 2 0} \text { crore }
\end{aligned}
$$

After 40 years (15 August 1987) from freedom when corruption $C=5.60$ crore, $D(c)=$ ?

From (ii), D(c) $=0.70 \times[2]^{\frac{5.600}{0.500}}$

$$
\begin{aligned}
& =0.70 \times[2]^{\frac{9}{1}} \\
& =0.70 \times 256 \\
\therefore \quad \mathbf{D}(\mathbf{C}) & =\mathbf{1 7 9 . 2 0} \text { crore }
\end{aligned}
$$

After 50 years (15 August 1997) from freedom when corruption $C=11.20$ crore, $D(c)=$ ?

From (ii), $\quad D(c)=0.70 \times[2]^{\frac{11,50}{0.50}}$

$$
\begin{aligned}
& =0.70 \times[2]^{\frac{16}{1}} \\
& =0.70 \times 65536 \\
\therefore \mathrm{D}(\mathrm{C}) & =\mathbf{4 5 8 7 5 . 2 0} \equiv \mathbf{4 . 5 8 7 5 e}+\mathbf{0 0 4} \text { crore }
\end{aligned}
$$

After 60 years (15 August 2007) from freedom when corruption $C=22.40$ crore, $D(C)=$ ? From (ii), $\quad \mathrm{D}(\mathrm{c})=0.70 \times[2]^{\frac{32.40}{0.70}}$

$$
\begin{aligned}
& =0.70 \times[2]^{\frac{82}{1}} \\
& =0.70 \times 65536 \times 65536 \\
\therefore \mathbf{D}(\mathbf{C}) & =\mathbf{3 0 0 6 4 7 7 1 0 7 . 2} \equiv \mathbf{3 . 0 0 6 5}+\mathbf{0 0 9} \text { crore }
\end{aligned}
$$

Today, after 65 years (15 August, 2012) from freedom when corruption $C=31.6736$ crore, $\mathbf{D}(\mathbf{C})=$ ?

From (ii), $\quad \mathrm{D}(\mathrm{c})=0.70 \times[2]^{\frac{\mathrm{gn} .6 \mathrm{6se}}{\operatorname{cos0}}}$

$$
=0.70 \times[2]^{\frac{45,248}{1}}
$$




$$
=0.70 \times 4.1784 \mathrm{e}+013
$$

$$
\therefore \mathrm{D}(\mathrm{C})=2.9249 \mathrm{e}+013 \text { crore }
$$

After 70 years (15 August 2017) from freedom when corruption $C=44.80$ crore, $D(c)=$ ?

$$
\text { From (ii), } \begin{aligned}
\mathrm{D}(\mathrm{c})= & 0.70 \times[2]^{\frac{44.80}{\operatorname{cos0}}} \\
& =0.70 \times[2]^{\frac{64}{12}} \\
& =0.70 \times[2]^{\frac{\mathrm{gn}}{11}} \times[2]^{\frac{\mathrm{gs}}{1}}
\end{aligned}
$$$$
\therefore \mathrm{D}(\mathrm{C})=1.2913 \mathrm{e}+019 \text { crore }
$$

Here, I have to use Applied Mathematical method. In this method I use initial values and Mathematical Growth formula for finding Mathematical Growth of Development Model. A slightly more realistic and largely used mathematical growth model is the logistic function and its extensions.

In the above data, I have observed that the development of such persons which have corrupted. This result on present situations because a lot of corruption ghotales are opens.

\subsection{Mathematical Result:}

I. The Relation between Development and Corruption:

$$
\therefore \quad \mathbf{D}(\mathbf{C})=\mathbf{D}(\mathbf{0}) e^{\mathrm{KC}}
$$

II. Mathematical E-virus constant $\mathbf{K}$ by using the relation as,

$$
\therefore \mathbf{K}=\frac{1}{c} \log \frac{D(C)}{D(0)}
$$

III. Mathematical Corruption Growth formula: $\mathrm{C}=\boldsymbol{C}_{\mathbf{0}} e^{\mathrm{Kt}}$, when $\mathrm{K}>\mathbf{0}$

IV. Mathematical Constant Corruption level formula: $\mathrm{C}=C_{0}$, when $K=0$

V. Mathematical Decay of Corruption formula: $\mathrm{C}=\boldsymbol{C}_{\mathbf{0}} e^{-\mathrm{Kt}}$, when $\mathrm{K} \leq \mathbf{0}$

I have found the values of Development (general) related to the Corruption are in the tabular form:

\begin{tabular}{|l|l|l|}
\hline Time (years) & Corruption (crore) & Development (crore) \\
\hline 15 August,1947 & 0 & 0.35 \\
\hline 15 August,1957 & 0.35 & 0.70 \\
\hline 15 August,1967 & 0.70 & 1.40 \\
\hline 15 August,1977 & 2.80 & 11.20 \\
\hline 15 August,1987 & 5.60 & 179.20 \\
\hline 15 August,1997 & 11.20 & 45875.20 \\
\hline 15 August,2007 & 22.40 & 3006477107.2 \\
\hline 15 August,2012 & $\mathbf{3 1 . 6 7 3 6}$ & $\mathbf{2 . 9 2 4 9 e + 0 1 3}$ \\
\hline 15 August,2017 & 44.80 & $1.2913 \mathrm{e}+019$ \\
\hline
\end{tabular}

The above table shows the Corruption and related Development in crores. Also I have observed that the Corruption increases and the Development decreases of the country India. The Graph of Corruption and Development shows the reality of the present situation in the country India.

\subsection{Mathematical Graph:}

From the above table, I draw the graph of Corruption and Development is as follows.

From the graph, It shows the development of the country India when Corruptions have removed completely from the society. That is when Corruption $\mathrm{C}$ tends to $C_{0}$ then the Development $\mathrm{D}$ will be increased to the high level.

Therefore, we can say that when the E-virus constant $\mathbf{K}$ tends to zero then $\mathrm{C}$ tends to $C_{0}$.

$$
\therefore \lim _{\mathrm{K} \rightarrow 0} C=C_{0}
$$

Then the Development $\mathrm{D}$ will be really development of the society of any Country in the world. 


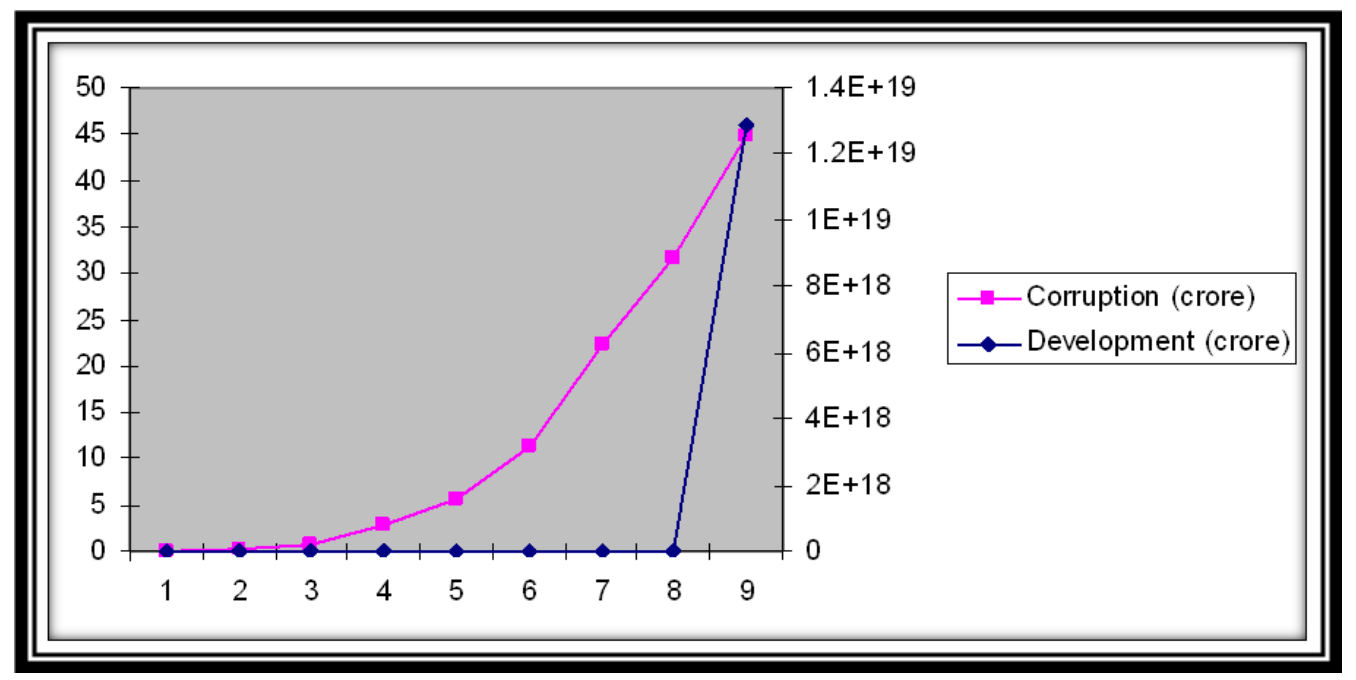

This is the 'Comparatively Mathematical Study Model Base between Corruption and Development'.

\section{Conclusion:}

In this paper, we will try to study on the problem of 'corruption' in the society by using Mathematical modeling techniques. From the above two illustrations we have observed and it concluded that if the population growth will increase exponentially then the quantity of corruption will increase exponentially also and the growth of corruption depends on the Mathematical E-virus constant $\mathbf{K}$. When $\mathbf{K}>\mathbf{0}$, the growth of (+ve) corruption will increase to the high level and at that time development of the society of any fields will decrease. When we will control the Mathematical E-virus constant $\mathbf{K}$ that is $\mathbf{K} \leq \mathbf{0}$, the (+ve) corruption will decrease to the Mathematical constant corruption level, at that time development of the society will increase of any fields or any country of the world.

Also we know that "Mathematical modeling and its applications" is a process of solving a particular type of problem generated by corresponding situations of the real world. The transformation from the real world to mathematics is achieved through the use of a mathematical model, which, briefly speaking, is an idealized (simplified) representation of the basic characteristics of the real situation through the use of a suitable set of mathematical symbols, relations and functions and mathematical model building involves imagination and skills. So we say this is the 'Comparatively Mathematical Study Model Base between Corruption and Development.'

\section{References:}

[1] George F. Simmons, Differential equations with applications and historical notes, McGraw Hill, New York (1991)

[2] Daniel A. Murray, Introductory course in Differential equations, Orient Longman ltd. Harlow and London (1993).

[3] P. N. Wartikar, J. N. Wartikar, Text Book of applied mathematics, Gajanan sant, vidyarthi griha prakashan, Pune (2002).

[4] Bhaskar Dasgupta, Applied Mathematical Methods published by Darling Kindersley (India) Pvt. Ltd. Delhi.

[5] Zafar Ashan, Differential equations and their applications, prentice hall of India, New Delhi (1999).

[6] Treilibs, V; Burkhardt, H; and Low,1 (1980). Formulation processes in Mathematical Modelling; Nottingham: shell centre for Mathematical Education.

[7] Moscardini, S. (1989), In W. Blum, M. Niss and I. Huntley (Eds.); The Identification and Teaching of Mathematical Modelling skills.

[8] S. J. Lamon, W. A. Parker \& K. Houston (Eds.); Mathematical Modelling: A way of life Chichester: Harwood Publishing. Chicheste: Ellis Harwood; Modelling, Applications and applied problem solving.

[9] Christopher Haines, Peter Galbraith, Werner Blum and Sanowar Khan; Mathematical Modelling ICTMA (12), Horwood Publishing, Chichester, UK.

[10] Frank R. Giordano, William P. Fox, Steven B. Horton and Maurice D. Weir; Mathematical Modelling Principles and Applications, Cengage Learning India Private Limited New Delhi.

[11] Roger J. Hosking, Ezio Venturino; Aspects of Mathematical Modelling Applications in Science, Medicine, Economics and Management, Birkhauser Veriag AG, Basel-Boston- Berlin. 